\title{
Triterpenoid from the Extract of Mangifera indica L. Roots Having Antispermogenic Activity
}

\section{KAUSHIK CHAKRABORTY ${ }^{1}$, AJAY KUMAR DAS ${ }^{2}$, SUBHASH C MANDAL ${ }^{3}$, BIPLAB DE ${ }^{4}$ and RATNA CHOUDHURY ${ }^{5 *}$}

\begin{abstract}
'Department of Pharmacology, Agartala Govt. Medical College, Agartala, Tripura, India. 2Department of Biochem., ICARE Institute of Medical Scs. \& Research, Haldia, West Bengal, India. ${ }^{3}$ Departmentof Pharmaceutical Technology, Jadavpur University, Kolkata, West Bengal, India.

${ }^{4}$ Regional Institute of Pharmaceutical Science And Technology, Agartala, Tripura, India. ${ }^{5}$ Henry Derozio Academy, Kunjaban, Agartala, Tripura - 799006, India.

${ }^{*}$ Corresponding author E-mail: drmrsratnachoudhury@yahoo.in
\end{abstract}

http://dx.doi.org/10.13005/ojc/310157

(Received: December 06, 2014; Accepted: January 11, 2015)

\section{ABSTRACT}

In vitro antispermogenic activity of an isolated triterpenoid from the extract of the root of the plant Mangifera indica L. was evaluated. The structure (3-O-acetyl-11,19-dinor-12,20-dimethylursane) was confirmed by the help of different spectral analysis.

Key words: Antispermogenic, Triterpenoid, Mangifera indica L.

\section{INTRODUCTION}

In continuation of our search on antispermogenic activity ${ }^{1,2}$ and interest on Mangifera indica L. roots ${ }^{1}$, we are reporting a new pentacyclic triterpenoid having antispermigenic activity.

Different parts of the plant Mangifera indica L. are commonly used as folk medicine for a wide variety of remedies like treatment of bleeding hemorrhoids, jaundice, cough, asthma, bronchitis, fever, piles, toothache, anemia, skin disease, leprosy, anthelmintic, wounds, diabetes, urinary tract infection, rheumatism, gastric disorder, syphilis and as carminative..$^{3-5}$ Many steroidal compounds and triterpenoids from Mangifera indica $\mathrm{L}$. were also reported. ${ }^{6}$

\section{MATERIAL AND METHODS}

Roots of $M$. indica were collected from Agartala, Tripura in Dec, 2012 and dried under shed, powdered (100 gm obtained) and then extracted in 
Soxhlet apparatus (10 gm in $100 \mathrm{ml}$ solvent system [Ether : Ethylacetate $=1: 1]$ ) with the aim of obtaining triterpenoid compounds. The total content of extracts was chromatographed in a glass made column (50 $\mathrm{cm}$ in length and $2 \mathrm{~cm}$ in diameter) using silica gel (60-120 mesh) as stationary phase and chloroform : methanol $=60: 40$ solvent system was used as mobile phase.

The structure of $3^{\text {rd }}$ fraction was elucidated by the help of IR, NMR \& MS. The purity of the isolated compound was confirmed by LC-chromatogram in LCMS-Shimadzu 2010A spectrophotometer as compound showed single peak at $0.573 \mathrm{mAbs}$ at $254 \mathrm{~nm}$.

IR spectra $(\mathrm{KBr})$ was recorded on a Jasco FTIR-5300 spectrophotometer. $\mathrm{H}^{1}$-NMR and $\mathrm{C}^{13}$. NMR recorded in Bruker AC-F 300 FTNMR and Mass in Shimadzu - 2010A.The isolated antispermogenic compound with molecular weight 470 deduced from its LC-MS APCI positive mode mass spectrum by exhibiting a molecular ionic peak at $\mathrm{m} / \mathrm{z} 471$ for $[\mathrm{M}+\mathrm{H}]^{+}$ion.

Compound ( $3^{\text {rd }}$ fraction) dissolved in DMSO (1 mg/ml) was mixed to sperm volume (1 ml) in the ratio of $1: 10$ and sperm count motility was assessed microscopically by following standard procedure..$^{1,2}$

\section{RESULTS AND DISCUSSION}

Total five fractions were collected separately after column chromatography, concentrated, dried under reduced pressure. The collected weight of fractions from first to last were
$15,13,22,10$ and $12 \mathrm{mg}$ respectively. Among those, the $3^{\text {rd }}$ fraction $(22 \mathrm{mg})$ showed promising antispermogenic activity, the $2^{\text {nd }}$ one $(13 \mathrm{mg})$ showed negligible percentage decrease in sperm count motility ( $13 \%$ after $30 \mathrm{~min})$ and other fractions did not show any antispermogenic activity.

IR ( $\lambda$ max) $\mathrm{KBr} 2926$ (C-H str of $\left.\mathrm{CH}_{3}-\mathrm{CO}-\right)$, 2854 (C-H str), 1705 (-C=O str) cm $\mathrm{cm}^{-1}$. In its $\mathrm{H}^{1}-\mathrm{NMR}$ spectrum (in DMSO $\mathrm{D}_{6}+\mathrm{CDCl}_{3} \mathrm{Mix}$ ) it exhibited peaks for eight tertiary methyl groups at $\delta 0.57,0.69$, $0.71,0.75,0.80$ and at $0.89 \mathrm{ppm}$. Further it exhibited peak at ' $1.15 \mathrm{ppm}$ for the $\mathrm{H}$ present in 6 membered alicyclic ring. A strong singlet at ' 2.06 might be due to a methyl group attached to a carbonyl group. Peaks at $\delta 2.47,2.48,2.49 \mathrm{ppm}$ recorded due to the $-\mathrm{CH}_{2}$ and $-\mathrm{CH}$ of alicyclic ring adjacent to -OCO-R. A probable structure of the compound was developed as fig. 1 (3-O-acetyl-11,19-dinor-12,20dimethyl-ursane).

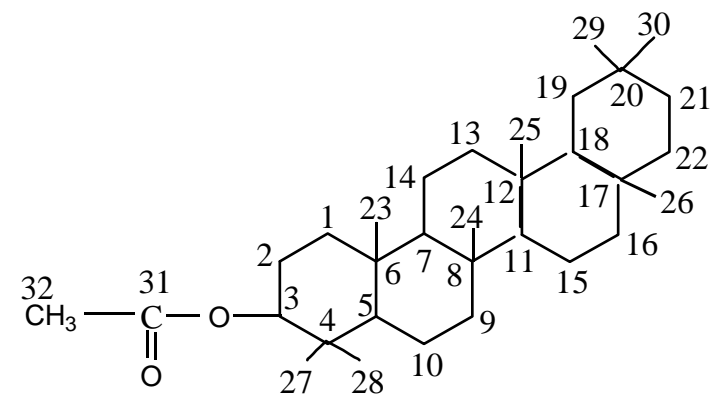

The $\mathrm{C}^{13}$-NMR data of the compound supported the structure of fig. 1 as recorded in ppm that $\mathrm{C} 1$ at $38.44, \mathrm{C} 2$ at $26.78, \mathrm{C} 3$ at $76.90, \mathrm{C} 4$ at $37.48, \mathrm{C} 5$ at $55.41, \mathrm{C} 6$ at $19.20, \mathrm{C} 7$ at 33.62, C8 at $37.10, \mathrm{C} 9$ at $46.80, \mathrm{C} 10$ at $38.80, \mathrm{C} 11$ at 24.50 ,<smiles>CC1(C)CC[C@H]2CCC3C(CCC4C3(C)CCC3C(C)(C)C=CCC34C)C2C1</smiles>

$\mathrm{m} / \mathrm{z}=383$<smiles>CC1(C)CC[C@H]2CCC3C(C)(CCC4C3(C)CCC3C5(C)CC=CC(C)(C)C5CCC34C)C2CC(C)(C)CC1</smiles>

$\mathrm{m} / \mathrm{z}=411$

$$
\text { (i.e. }\left[\mathrm{M}-\mathrm{CH}_{3} \mathrm{COOH}+\mathrm{H}\right]^{+} \text {) }
$$

$\mathrm{m} / \mathrm{z}=397$ (Base peak) 
C12 at 18.50, C13 at 37.22, C14 at 42.20, C15 at 28.86, C16 at 23.22, C17 at 35.40, C18 at 53.10, $\mathrm{C} 19$ at 40.76, C20 at 40.34, C21 at 28.29, C22 at 28.35, C23 at 14.56, C24 at 20.87, C25 at 13.59, C26 at 22.23, C27 at 29.86, C28 at 29.29, C29 at 11.38, C30 at 11.17, C31 at 171.92 and C32 at 79.36 .
Further, mass spectra fragments confirmed the structure as in fig. 1.

In vitro antispermogenic activity of isolated triterpenoid compound was carried out. Percentage decrease in sperm count motility is the indicator of spermicidal activity. The isolated triterpenoid compound showed percentage decrease in motility $14 \%, 22 \%$ and $31 \%$ in average respectively after $10,20,30 \mathrm{~min}$.

\section{REFERENCES}

1. De, B.; Momin, Z. Ch.; Sen, S.; Chakraborty, R.; Goswami, B. B.; Oriental J. Chem. 2010, 26, $1067-1069$.

2. Debnath, M.; De, B.; Bhattacharjee, P. R.; Choudhury, R.; Choudhury, P. S.; Advances in Pharmacol. And Toxicol. 2006, 7, 23-25.

3. Anonymous, The wealth of India: A Dictionary of Indian Raw Materials and Industrial Products, Publication \& Information
Directorate CSIR. New-Delhi, $1^{\text {st }}$ supplement series (Raw materials), Vol. 2, (2007).

4. Wauthoz, N.; Balde, A.; Balde, E. S.; Damme, M. V.; Duez, P.; Int. J. Biomed. Pharm. Sci. 2007, 1, 112-115.

5. Parekh, J.; Chanda, S.; Afr. J. Biotechnol. 2008, 7, 4349-4353.

6. Anjaneyulu, V.; Radhika, P.; Indian J. of Chem. 2000, 39B, 883-885. 